Freedom in Practice: Governance, Autonomy and Liberty in the Everyday

Moises Lino e Silva and Huon Wardle [PREPUBLICATION VERSION] (2016)

'Zora, you've come to de right place if lies is what you want. Ah'm gointer lie up a nation'

George Thomas to Zora Hurston ([1935]1990:19).

\title{
John Brown: Freedom and Imposture in the early Twentieth Century Trans-Caribbean
}

\section{Prologue: 'English Subjects'}

At some point during February 1910, John Brown, came to the attention of the Foreign Office in London. Described in official documents as the 'personal servant' of English explorer Captain T.W. Whiffen, Brown had testified to the Commissioner of the British colony of Montserrat about acts of violence committed by Peruvian 'captains' against both Amerindians and 'English subjects' (West Indians) working in the Putumayo sector of the Amazon jungle. Having himself escaped to the local capital, Iquitos, Brown told how he had meant to go directly to London to inform the colonial office about the actions of those running the Peruvian Amazon Company, but he had now ended up giving his testimony on the Caribbean island instead:

They still continued beating and ill-treating us English subjects, and they treated the Indians in the same way. The cruelties they practised in that place are shameful... When we objected to this treatment they told us they did not care what they did with English subjects. They called us pigs and dogs and all sorts of names, and said that King Edward the seventh was nothing but a dog, and that the president who sits in Lima is the King of the world...

I had intended to go to England by the Booth Line Steamer in order to report the story of our sufferings to the Secretary of State, but before I was ready I met with a gentleman called Captain T.W. Whiffen... ${ }^{1}$

Already alerted to the situation in the Amazon by allegations in the British newspapers made by an American traveller, Walter Hardenberg, this further testimony by Brown-the eye-witness statement of an imperial subject - had potential as evidence in a mounting case against the PAC, a London registered syndicate with British employees. It would, in fact, help trigger what would become a world-famous investigation by Sir Roger Casement into 'a crime against humanity'2the enslavement and massacre of Indians in the North West Amazon. 
Freedom in Practice: Governance, Autonomy and Liberty in the Everyday Moises Lino e Silva and Huon Wardle [PREPUBLICATION VERSION] (2016)

However, individually written minutes, added to the document by Colonial Office officials, indicate certain reservations:

This account of Whiffen's "boy" was promised us sometime ago but now that it has arrived it is difficult to say how much credence ought to be attached to his statements (especially as the unusually good English he writes is rather suspicious in the case of the West Indian negroes)...

We might send a copy of John Brown's statement to the [Peruvian Amazon] company saying that in our opinion it strengthens the case for a commission of enquiry...

[The Peruvian Amazon Company] would merely retort that Captain Whiffen's black servant was not a credible witness...

We ought to get some answer from the Americans... ${ }^{3}$

In both Brown's rhetoric and these handwritten notes swirl eddies and contrary streams of a colonial worldview. Brown presses his claim as 'an English subject'. In turn, colonial officials acknowledge that his statement 'strengthens the case' for an enquiry while simultaneously gesturing at the authority of race and class-'unusually good English...', 'Captain Whiffen's black servant...' - in order to cast doubt on its credibility. There is a double bind at work in the documents from the point of view of the officials: the word of an 'English subject' is

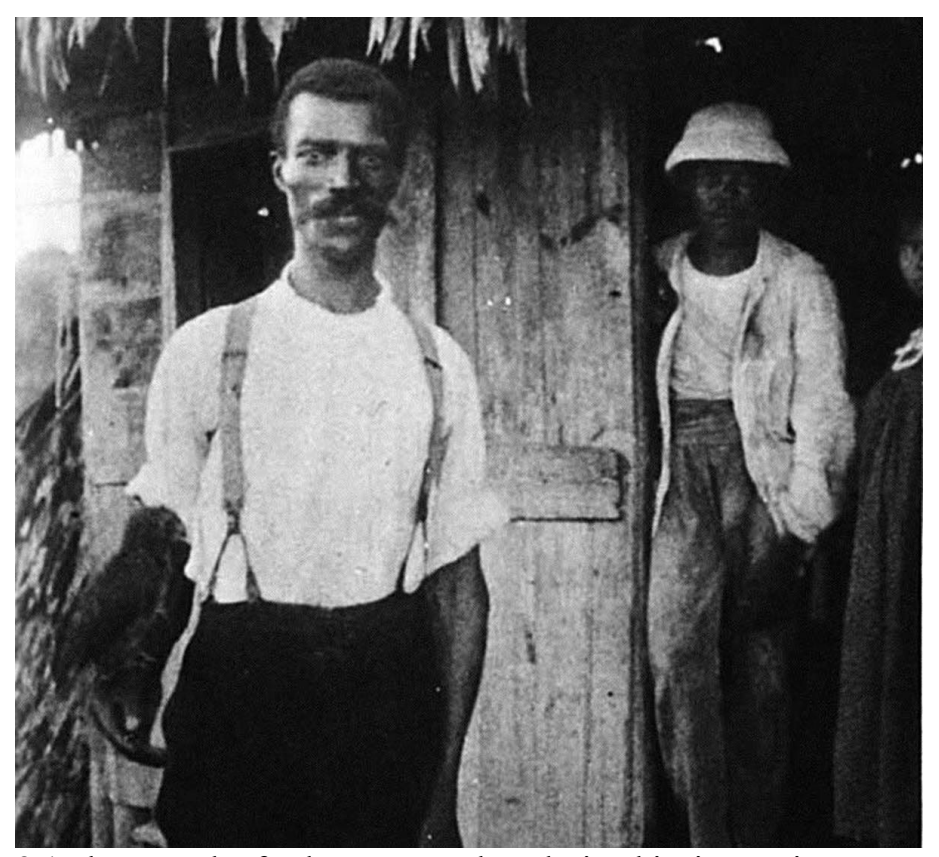

3.1 Photograph of John Brown taken during his time as interpreter to the consular expedition to the Putumayo, 1912 (see Chapparro, worth more than that of a Peruvian, but how can the voice of a 'black servant' count credibly against the reputation of a wealthy Londonbased company? Either way, under the terms of the Monroe doctrine, and in the face of growing U.S. 'dollar diplomacy' in South America, the Colonial office must not act 
without 'some answer from the Americans'.

Beyond this sense, though, that the race-class hierarchy in the West Indian colonies was being upset by Brown's assertions, from one viewpoint at least, the colonial mandarins had intuited rightly that there was something unusual about John Brown: because, despite his claim to Captain Whiffen that he was a Barbadian, and later to Casement that he was a 'native of Montserrat', Brown was neither. He was not, in fact, even an 'English subject' - not, that is to say, any type of denizen of the empire of His Majesty, King Edward the Seventh, yet, under this label, Brown would actively establish the facts about the Putumayo not only for Whiffen and Casement but for the international Consular Expedition that ensued. 'The one who attempts to bring about changes in the order of human society becomes a dangerous creaturea dangerous impostor upon society, and to those who control the system of the day' (Marcus Garvey in Hill 2008:15).

\section{Introducing the Problem: Traces of an Individual's Search for Freedom.}

Where might freedom as a subjective and intentional quality leave its trace in the anthropological record? Kant defined Anthropology as the study of what humans make of themselves as 'free-acting' beings (see the introduction to this volume). ${ }^{4}$ However, in so far as social enquiry during the last fifty years has tended increasingly toward a hermeneutic reading of culture-deducing the formal properties of subjectivity from common discourses, shared habitual behaviours, structured dispositions and mutually acknowledged systems of truth ${ }^{5}$ - then we may reasonably answer, freedom is to be found nowhere. The migrant John Brown, the protagonist of this discussion of freedom, enters the historical record in 1910 most obviously as a pawn in a much larger game of imperial liberal policy. It would be simple, then, to view his life as a social outcome of the concatenation of circumstances extant in the Caribbean and South America immediately prior to the First World War. As we read closely, though, we come to recognise someone attending to the cracks and spaces in political rhetoric; conscious of how his search for freedom might be furthered underneath, in between, or by way of, the imposture that the colonial project demanded. What freedoms, then, were he and others around him imagining or trying for? Where might this imagining of freedom evidence itself?

Assessing John Brown's life vis-à-vis the structure and effects of early Twentieth Century British imperial liberalism is to say the least difficult-precisely, as Simmel points out, because liberal discourse at this time proudly signalled the unique success of its worldview by 
pointing to the unprecedented 'unpredictability' of its institutions and social arrangements (Simmel [1911] 2009:338). The establishment of a permanent 'age of discussion' and the continuous manifestation of new ways of participating in civic life were taken as marks of the preeminence of liberal policy in extending individual freedom globally; but so too was a generous attitude to archaic tradition and pageantry (Bagehot 1873). However, the interpretive problem lies deeper in this instance because it involves the fact that black migrants like John Brown, by way of many decades of travel across the Caribbean and Central and South America, had become experts at a form of cultural mimesis, remodeling and code-switching ${ }^{6}$ that allowed them to reshape the public expression of their worldviews and motives to fit with the signs of imperial power. Whatever subjective imagining of freedom they engaged in has, then, been doubly obscured historically. We know, though, noting the extraordinary success of Marcus Garvey in this era, that these migrants had a keen awareness of the utopianism, fantasy and imposture at the heart of British imperial project.

Certainly, codes of Britishness were deployed by black workers to invoke at least a semblance of civic equality against the politics of racial segregation enforced by North America as it took power in the region. The same codes were used tactically, as the case of John Brown in the Putumayo shows, as a means of escape from impossible conditions in South America. Hence we need to consider how the public rhetoric of imperial Liberalism at the turn of the Twentieth Century intersected with the freedoms that black workers made for themselves on the move. Migrants used and impersonated the language of British imperial liberty. However, for many reasons-not least the contradiction between the de jure principle versus the de facto enactment of race-andclass hierarchy-the terminology could never fit with individual attempts at localising freedom. It is this gap between subjective intention and public discourse, and its relation to the question of practical freedom, that I will explore here with John Brown's life in view. 


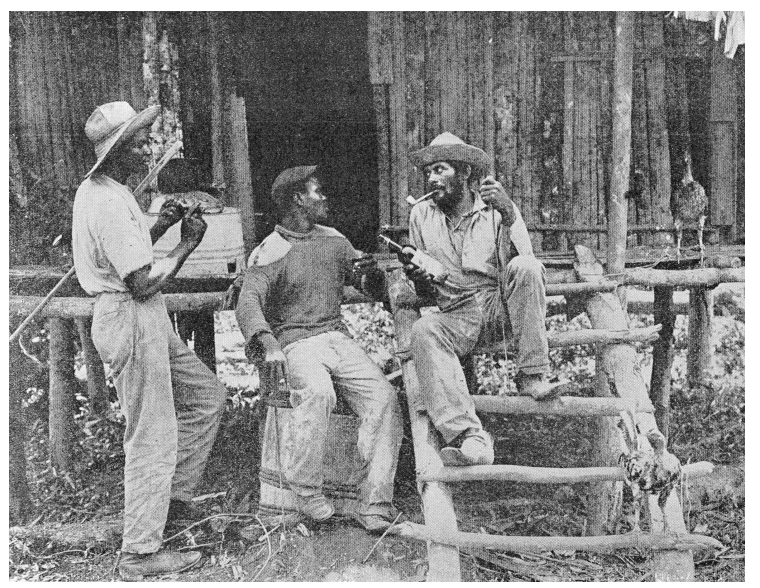

3.2 Workers in Panama (Abbot 1913:347). Emigrants from the British West Indies, collectively labelled 'Jamaicans' and or 'Barbadians' formed the largest source of labour for the grand industrial projects of the period in Central and South America.

His wayfaring across a vast geography and his search for certain immediate freedoms for himself as he went along are integral facts of John Brown's life. However, in the first years of the Twentieth Century this singular life-course became entangled in the forces at play in a very particular moment of transformation in South America; and this in turn changed the meaning of that life taken as a whole. Put another way, considering John Brown's biography while also attending to the global pattern and scope of the forces unleashed at this historical juncture opens up a series of enigmas of interpretation. While we puzzle over which view we should commit to in each case, or at each point of focus, the gaps between different interpretive frames become more obvious, the ambiguities become more tensely articulated. In the discussion that follows I offer a view of Brown as a cosmopolite, using this word, not in some celebratory or idealistic sense, but because none of the other possible identifications-Colombian, British, West Indian, Barbadian, African-American, deterritorialised or marginal man - that the various narrations of his life have thrown out make more than momentary sense of it. Brown's own commentaries suggest, integrally, a rejection of these labels-a sequential attempt at freeing himself from the impersonations demanded of him albeit combined with an appreciation of their value.

So I will again highlight one puzzle in particular: the practice of British imperial liberalism in the Circum-Caribbean region at this time made possible, perhaps encouraged, a strategy of bluff and masquerade vis-àvis the imperial rules of the game. American and British imperialism each created distinct typologies of imperial subject but failed to police 
the contradictions these threw up; and in turn avenues were opened for ambiguation or 'signifying' on the part of the people categorized (Gates 1988). Migrants could smuggle their distinct life projects-and the subjective search for freedom involved-into the shifting and conflicting configurations of imperial protocol. This, certainly, is one aspect of how John Brown's life turned out.

Answering who Brown was and why he came to be in the Amazon rubber belt at all tasks us, then, with unravelling the threads of imperialism in the Caribbean and Latin America at end of the nineteenth and the beginning of the twentieth centuries. British West Indian labour had, since at least the 1880s, become vital both to British and North American political-economic interests in Central and South America. During the late $1^{\text {th }}$ and Early Twentieth Centuries, Central and South America underwent rapid industrialisation by North American commercial interests. This was at the same moment that British imperial power in the region and the liberal philosophy of trade without borders had also reached its height. The massive rise at this time in speculative financial investment in industrial technology (especially railways; cf. Veblen 1904:22) amounted to what power law theorists call a bursty event: it instigated radically new kinds of social formation and counter-culture-and especially new kinds of violence.

For investors in industrial infrastructure in prospect were the profits to be made on raw material extracted from the South American hinterlands. A further effect was the rapid creation of new markets for commodities in these locations - for example the establishing of Iquitos in the 1900s as a wealthy hub of the rubber trade. In the case of Amazonian rubber this commodity (14 million pounds worth per year at the height of the boom) was being moved down the Amazon on British owned steam launches. By the early 1900s, the size of the British speculation in South American bonds, stock and shares was estimated at $£ 600,000,000$ returning average dividends of $5 \%$ per annum. ${ }^{7} \mathrm{But}$, an effect of Casement's investigations was to lay bare the violent breakingopen of local economies involved:

[T] he enormous increase in the world consumption of rubber... at present (1912) necessitates a supply of latex to the value of $£ 50,000,000$ per annum. The economic basis for the production of raw materials is a primitive system of exploitation practised by European capital... where the institutions of slavery and bondage are combined in various forms. 
John Brown found himself caught up in this vortex of imperial governance and finance capital. He would discover in the process that his life was tied to those of the hundreds of thousands of West Indian migrants traversing the Circum-Caribbean. In Freedom and Civilization Bronislaw Malinowski talks of how civic freedom is always a correlate of well-developed customary institutions-the institutions of a linguistically and culturally well-integrated community with strong shared traditions. The situation in the early Twentieth Century Caribbean is far from this picture. Together, workers on the move were building a new kind of social life just as they laid rail tracks and dynamite charges, getting the knack of the heavy machinery they worked with. Travelling, they entered new terrains, discovered and put together new social tactics and cosmopolitan techniques for talking across thresholds of linguistic and cultural incomprehension; learnt and redeployed an open-ended repertoire of symbols and ideas, thereby recreating their view of the world. Central to this process was the motif of being an 'English' or 'British subject'; terms which were inevitably remodelled, switched and or double-coded as people relocated themselves.

\section{Wayfaring}

John Brown is mentioned many times in the extensive literature on the Putumayo rubber boom and in almost all this writing, when he appears, he is described as a 'Barbadian'. But Brown never lived in Barbados. He was born in Chicago in 1879, the grandson of slaves from the South, his family part of the great migration after emancipation. He grew up near the city harbour in East $77^{\text {th }}$ street: a rapidly growing section often visited by foreign seafarers. The resonance of his name can hardly have been an accident: Brown's famous white namesake, the militant anti-slavery activist, had died twenty years earlier, but the reformer's family remained prominent, and for many heroic, figures. The Chicago Tribune for August 1882, when John Brown was three years old, reports of the abolitionist's widow and her sons attending a meeting in the city to promote African American migration to Haiti.

Certainly, there was little keeping the boy John Brown in Chicago, or in America for that matter. His father had recently died and he was the fourth of nine children. John and his siblings were illiterate with no likelihood of schooling (the Chicago South Shore district had not long before opened a school, but a contemporary photograph shows white pupils only). A search in the records of the Chicago public library turns up no sign of his family in the 1880 census. Whatever his motives, one night, at the age of nine, Brown stowed away on a boat across the lakes, 
making his way to New York. There, after living on the streets for a while, he followed a group of drunken French sailors up the gangway of their ship. Arriving finally in Paris he worked for a while as a hotel skivvy; then, from France, he travelled to Liverpool where he stayed for several years with a black seaman, James Henry, and his white Liverpudlian girlfriend, Margaret. Margaret taught John Brown to read. By now he was 15 and he went to sea again, this time as a stoker's mate, living and shoveling coal in the engine room of White Star Line, Royal Mail and other freight ships. He took routes between the Caribbean islands, Africa and Scotland for several years before finally becoming a stoker in his own right.

During shore leave in Glasgow, a fellow sailor had encouraged Brown to escape the filth and heat of the boiler room and to travel to Brazil to work in the booming rubber industry there. So, in 1902, Brown took a launch from Manaos up the Amazon to Iquitos, Peru. There, in a bar, he describes seeing for the first time an Amerindian woman and being smitten. His companions told him that up country were many like her living naked in the forest. To see them he should go into the Putumayan jungle and work for the House of Arana-the Peruvian Amazon Company - as a rubber tapper. Brown wanted to see for himself, but one Barbadian worker, passing through, warned him-'Bad. They kill people there. There are wild indians. They say people never come back' (Gomez 1984:34 my trans.).

Most of what we know for certain about John Brown is available to us because he narrated his life to Colombian author Pedro Gomez Valderrama in 1960 in Bogota (1984). In this short written account, Gomez retells Brown's life story as a series of personal escapes from one 'hell' into another. However, John Brown's life is, also, refracted in other ways through the seeing-imagining-writing of the many visitors who encountered him during the decades he spent in the Putumayo. Written accounts mentioning him stretch from 1910 well into the 1970s and these are, of course, refigured once again as we draw inferences and try to rethink the viewpoints involved. Here and there in the documents we glimpse Brown adopting a stance strategically: to different interlocutors he describes himself variously: to Captain Whiffen, Sir Roger Casement and other representatives of British colonial authority, he is a Barbadian, perhaps also a Trinidadian, later Montserratian, hence always 'British' or 'English'. To Gomez in 1960 Brown says that Colombia is his homeland; others take him for an American and he agrees. Brown appears in travelogues and interviews. Some have recognised him as an evil character in La Voragine, Jose Eustasio Rivera's documentary-style novel of lovers lost in the 
Freedom in Practice: Governance, Autonomy and Liberty in the Everyday

Moises Lino e Silva and Huon Wardle [PREPUBLICATION VERSION] (2016)

Colombian jungle, though Brown dismissed its author as someone who had never even visited the Putumayo9. John Brown may also be present in oral histories told by Bora indians to anthropologist Mireille Guyot in the 1960s:

according to my grandmother... there was [living amongst the whites at the Santa Catalina and Abisinia camps] a man, black in colour, who spoke the Bora language, but she did not know the name of this man who was so good [que era tan bueno] (in Chirif 2004:62 my translation). ${ }^{10}$

During his own lifetime, Brown made various attempts to correct the records others had made of him. Ramiro Rojas Brown, his grandson, has attempted to intercalate these, navigating the contradictions and lacunas (2010). How, though, did Brown envisage his world, what rules did he apply to his own behaviour and what liberties did he knowingly take for himself, or take himself to be taking? What, to paraphrase R.G. Collingwood, were the questions to which the pattern of his life was the attempt at an answer (1978)? Recovering something of his individual world-knowledge and his intentionality involves us in recapturing the more general experience of a highly mobile black workforce in this epoch. As we have noted, though, there is a question here of establishing which labels and contexts should count.

\section{Amongst the Emigrants}

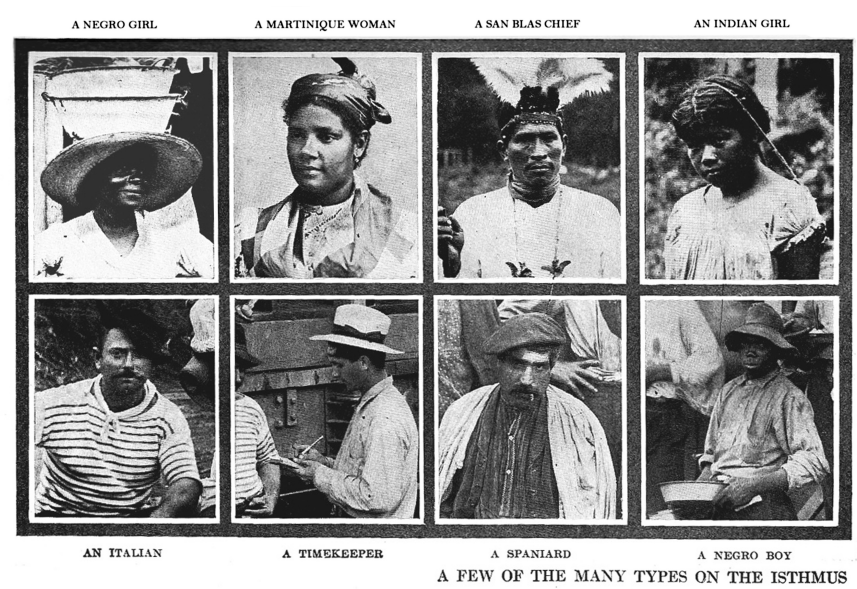

3.3 "A Few of the Many Types on the Isthmus" in Haskin 1913:274. Racial typologising and segregation were fundamental to the organisation of labour on U.S. led projects in Central America.

In his statement to the Montserratian Commissioner in 1910, Brown had said truthfully that he arrived in Iquitos in 1902. Later the same year in Iquitos, though, he would tell Sir Roger Casement that he had come to 
the Putumayo with a group of fellow 'Barbadians' contracted out of the island capital Bridgetown during 1904 and 1905 (Johnson 1998). As we will see, Brown had lied for a specific reason: if his story did not match that of the other black workers in the Putumayo it would put in question the raison d'etre for Casement's inquiry which was to protect the rights of the 'British subjects' working there: he might, in the process, be putting the lives of his fellow workers in jeopardy. Brown had become caught up in a play of interests over which he had little control, but regarding which he had a great deal to lose. To understand why at this moment John Brown presented himself as a 'Barbadian' or 'Englishman' we need to recognise how West Indian colonial workers had become instruments in an international pattern of capitalist profit extraction in South America. However, at the same time, we need also to comprehend that, from their perspective, subjectively and collectively, their migrations constituted a sequence of assays toward freedom.

After slave emancipation in the British Caribbean in the 1830s, anglophone West Indians had quit the sugar plantations en masse and many thousands began to emigrate, ${ }^{11}$ both to secure subsistence for themselves and their families, but also as a complexly fused act of escape, defiance and 'betterment' (Senior 2014). This mass movement is referred to by historians and anthropologists as a 'flight from the estates' or as a transitive process of 'fleeing the plantation': anthropologists have come to see this response to emancipation not merely as a negation of the slave estate system, but as generating new kinds of networks of social relationship, new kinds of freedom, as well as revised worldviews. In particular, to use Thomas-Hope's phrase, emancipation demanded and triggered a radical 'reorientation of self' in the world (1995:161).

The ability of former slaves to reinvent themselves in the postemancipation landscape as British or English imperial subjects is a striking feature of the emergent pattern after emancipation. The kinds of claim involved were often commented on, with some puzzlement, by white colonial officials:

The present writer has, in South America, been hailed as a "fellow countryman" by chance Barbadoes men, with that singular cordiality which is one of their characteristics. "How do you do, sir! I'm an Englishman too," they will say with outstretched hand (Enock 1912:40, fn). 
'They do not act as humble colonials... but as equals politely greeting a visiting stranger' comments another (in Olwig 2010:419). The normative colour of Englishness was white and the official homeland of Englishness was far away across the Atlantic, but imperial ideology was, as PJ Wilson puts it, 'schizoid' (1974:119). In civic-juridical terms all imperial subjects were equally Britons, and the white colonial official should acknowledge this since the empire denigrated American racial prejudice and the mistreatment of its subjects (e.g. Clark 1997:92, Rush 2011). For their part, into the overarching assertion of equal citizenship, West Indians could wedge further meanings that were distinctive to their individual lives and conditions, but which remained hidden from the view of the colonial administrator.

This schizoid character of British imperialism appears in Casement's report on the Putumayo events and even more startlingly in witness testimony to the Parliamentary Select Committee inquiry that followed with its strange and incoherent shifts of moral key as they tried to adapt their position to the British liberal imperial ideal. ${ }^{12}$ As we have seen, the technological infrastructure for removing rubber from the Amazonian interior was British controlled-(notably the Booth steam-line mentioned by Brown in his witness statement); but the violence needed to force local peoples to accumulate the rubber had been delegated to Peruvian overseers. Only when 'British Subjects' became visibly caught up in this violence did it become necessary to ensure that the liberal worldview was not fundamentally damaged.

Sometimes, though, hidden features of a doubly coded worldview become visible. In 1910, Jamaican workers on the banana plantations of Costa Rica struck in protest at withdrawal of wages and the use of torture by American overseers. When they appealed to the British Consul in San Jose his response was to tell them that they were better off returning to work as 'free men' than being returned by force-as slaves in effect-thereby washing his hands of the issue (Chomsky 1996:162). However, West Indians had someone else they also referred to as 'the Consul' - one of the strike leaders, Jamaican Charles Ferguson. Apart from his role as a labour organiser, Ferguson was a recognised obeah man, in other words a sorcerer. He actively protested against the failure of the colonial representatives to protect British subjects working there. Other labour activists in Costa Rica included Jamaican migrant J. Washington Sterling, accused in Limon of practicing medicine illegally-Sterling was almost certainly likewise a 'medicine man', a sorcerer. ${ }^{13}$ In this same year, West Indian workers in the Putumayo would tell Casement that, while the British Honorary Consul in Iquitos, David Cazes, was in the pocket of Arana's Company, they, nonetheless, 
Freedom in Practice: Governance, Autonomy and Liberty in the Everyday

Moises Lino e Silva and Huon Wardle [PREPUBLICATION VERSION] (2016)

had their own 'Barbadian Consul' - an elderly migrant called Carlton Morris who also lived in Iquitos. ${ }^{14}$ Casement took these references to be jocular, but almost all the workers in the Putumayo were young men in their twenties. Amongst them, John Brown, at 32, was one of the oldest. Was Morris, then, a much older West Indian, also an obeah or medicine man? The circumstantial evidence is at least suggestive of a deliberately obscured worldview for which we retain only fragmentary evidence.

Likewise, in 1910, another itinerant worker, Marcus Garvey, who would become the most successful black activist of the early Twentieth Century, arrived in South America to take up a position as a 'timekeeper' on a Costa Rican banana plantation. He would spend some of the first years of his adult life roving through Central America, going as far south as Ecuador to visit the West Indian workers there; a journey of some two thousand miles from Jamaica. 'Peoples everywhere are travelling toward industrial opportunities and greater political freedom', he would note later (1967:7). Garvey was quickly recognised by the authorities as a subversive, initially because of his attempts to organise elaborate local festivities for the coronation of emperor George V (Edward VII having died in May) without first consulting the British vice consul. John Brown's travels into the Amazon predated Garvey's and he makes no mention of him, but the philosophy that Garvey would begin to preach, itself learnt from of his own experiences of work in the new industrial sites of South America would have made good sense to him: 'the whole world is run on bluff. No race, no nation, no man has a divine right to take advantage of others. Why allow the other fellow to bluff you?' (Garvey 1967:7). In his own public performances Garvey tapped into elements of the 'bluff', imposture and comic opera in British imperial liberalism that were clearly visible to West Indian migrants. There was an underlying aim: 'we are going to emancipate ourselves from mental slavery because whilst others can free the body, none but ourselves can free the mind' (in Hill 1991:791).

\section{Hunting Cities - the search for freedom in and beyond the U.S.}

Emancipation in the U.S. after 1865 engaged similar processes of reinvention and double-coding, though in political-economic terms the situation there was fundamentally distinct. Many emancipated Southern slaves, like John Brown's grandparents, left from the South toward the Northern cities, often changing their names to shed the vestiges of the past, not only to realise freedom and to find work, but also to escape the racist violence that followed emancipation and 
Freedom in Practice: Governance, Autonomy and Liberty in the Everyday

Moises Lino e Silva and Huon Wardle [PREPUBLICATION VERSION] (2016)

reconstruction. Writer Mark Twain catches a vivid glimpse of this in his Life on the Mississippi. Recently emancipated slaves, he writes,

stay on a plantation till the desire to travel seizes them; then they pack up, hail a steamboat, and clear out. Not for any particular place; no, nearly any place will answer; they only want to be moving. The amount of money on hand will answer the rest of the conundrum for them. If it will take them fifty miles, very well; let it be fifty. If not, a shorter flight will do (1883:113).

In the 1930s, Lee Guidon, born a slave in Arkansas, commented wryly on these movements to a member of the Federal Writers Project:

After freedom a heap of people say they was going to name their selves over. They named their selves big names then went roaming round like wild, huntin' cities. They changed up so it was hard to tell who or whar anybody was. Heap of em died an' you didn't know when you hear 'bout it if he was your folks hardly. Some of the names was Abraham and some called their selves Lincum [sic. Lincoln]. Any big name 'captin' their master's name. It was the fashion. 15

The invention or appropriation of a new name in this situation was, as Sue Benson indicates, a statement about the freedom of that person: in particular it was an assertion of the 'uniqueness of the individual so named' and of the removal of social ties to a particular history and locality (Benson 2006:195). Many thus erased their connection to the sites of slavery, but only a few (how many it is impossible to say) would, like John Brown, join a further movement of Caribbean workers into Central and South America. Amongst the reasons for avoiding the region may have been the fact that the new industrial work available was, very largely, run by U.S. companies who administered their projects on the basis of racial segregation. When they did travel, black migrants from the U.S. found themselves grouped not with their privileged white compatriots but instead with the much larger, already well-established, black workforce from the West Indian islands (Greene 2009: 99). 


\section{The Tactics of Freedom - 'making the sign of the cross'}

We cannot understand an individual's experience of freedom without understanding the constraints that are part of its expression. The bulk of the migrant work in the circum-Caribbean region after emancipation took the form of massive engineering projects - first a French organised railway across the Panama isthmus in the 1850s, then the initial French attempt at a trans-oceanic canal (finally completed by the United States in 1914), subsequently a sequence of mostly U.S.-led railway projects in Costa Rica, Nicaragua, Colombia, Ecuador, Brazil and Peru. The canal and the railways speeded the path of commerce, maximising the power of extractive industries working the Andean mines and the Amazonian forests to bring industrial materials to the factories of North America, Britain and Germany.

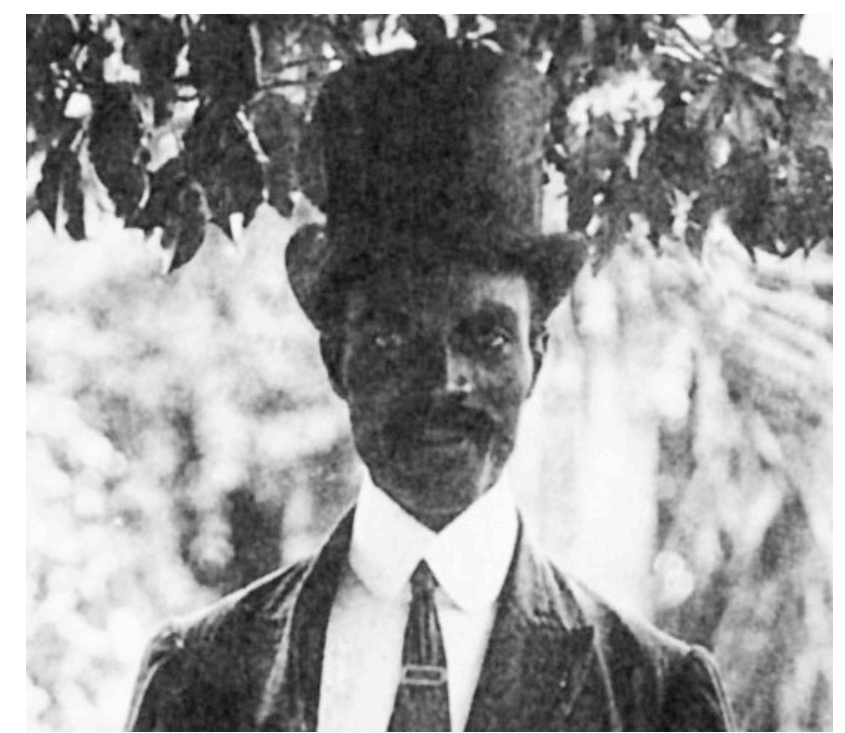

3.4 Portrait of Brown taken by Capt. Whiffen, detail (see Cadbury 2004).

In this regard, Britain and the U.S. had rival interests in South America. However, a symbiotic relationship had developed in which Anglophone West Indian labour became crucial in the capitalisation of U.S. controlled assets in the region, while emigration also allowed an outlet and income for West Indian island economies that had been in deep decline since the collapse of the sugar estates. A case in point is Minor C. Keith's United Fruit Company which is unlikely ever to have existed in the form it took had not Jamaican workers supplied labour first on his railways, then expertise in growing and cropping the hybrid Gros Michel or 'Big Mike' bananas he grew alongside the tracks. The Jamaican workforce were also therefore unwitting participants in the making of the 'banana republics' that sprung up wherever United Fruit gained political and economic dominance; gradually, though, 'Jamaican' labour would become politicised and organised in its own right (Chomsky 1996).

Many West Indian workers moved from one of these projects to the next labouring on fixed-term indentured contracts. Some moved on to the U.S. itself, to Harlem in particular where they would play a central 
role in the Harlem Renaissance and in Marcus Garvey's black internationalist movement. Behind they left a trans-territorial network of relationships that still exists today. Of this period of massive industrial transformation, we retain only glimpses of how those involved experienced it: to gain more insight, we need to recognise the mass movement of labour across the region as a socio-cultural event interpretable in its own terms. We know that, in the places where they arrived, the migrants learnt to invent and localise a range of revised political tactics out of ad hoc materials..

Discussing Caribbean mobility, Crichlow points out that we run into trouble when we demand that the search for freedom should correspond to some absolute teleological transcendence of existing social conditions (2009). For example, R.D.E. Burton criticises Caribbean cultural politics for making a show of subversion while allowing fundamental hierarchical structures to remain in place. There is no room in this kind of account, Crichlow responds, for the 'ironies and paradoxes' by way of which freedoms may be achieved proximally or situationally: nor, it could be added, for understanding how projects toward freedom may be concealed underneath conservative symbols forms and 'limbo-ing' struggles for freedom as Wilson Harris describes them (Harris 1970, Reisman 1971, Sheller 2012). Instead she suggests that the tactics involved in 'placing' or 'homing' freedoms in the lives of Caribbean migrants are better understood by analogy with making the sign of the cross: analogically a cross is a compromise between a vertical or hierarchical gesture and a horizontal or egalitarian one. Rather than representing some absolute (hence impossible) act of utopian transcendence, from this perspective freedoms are realised as a compromise between the demand that power be acknowledged and the ability to create a degree of equality in the particular situation (Crichlow 2009:75-76). The high seriousness of the cross as icon belies its characteristic Afro-Caribbean use as the great, perhaps the ultimate, ambiguator. These views certainly correspond much more closely to the everyday experience of the meaning of 'freedom' than to analytic arguments that would rule freedom out a priori. It may also offer the only way of resolving the apparent paradox that people seek subjective freedom in modes of social activity that are shown to extend their exploitation once we are in a position to view the total historical situation with hindsight. 
Freedom in Practice: Governance, Autonomy and Liberty in the Everyday

Moises Lino e Silva and Huon Wardle [PREPUBLICATION VERSION] (2016)

\section{The impostors}

Nowhere is this tactical understanding of freedom more clear than in Brown's relationship with the young explorer Captain Thomas Whiffen. Brown met the captain in the regional capital, Iquitos in 1908 when, by his own account, Brown had meant to leave the Putumayo permanently. Whiffen's aim, following in the footsteps of the Eugene Robuchon who had mysteriously disappeared a few years before, was to study the 'cannibal tribes' of the North West Amazons. Contrastingly, Brown's intention in becoming Whiffen's servant, as he explained to Gomez many years later, was that Whiffen should witness what was being committed by the House of Arana and carry news of the atrocities to Britain. Each, we might say, was engaged in a complex act of impersonation and dissimulation that depended on the 'schizoid' character of British imperial ideology - each was also in his own way seeking certain kinds of freedom, each was in key respects an impostor.

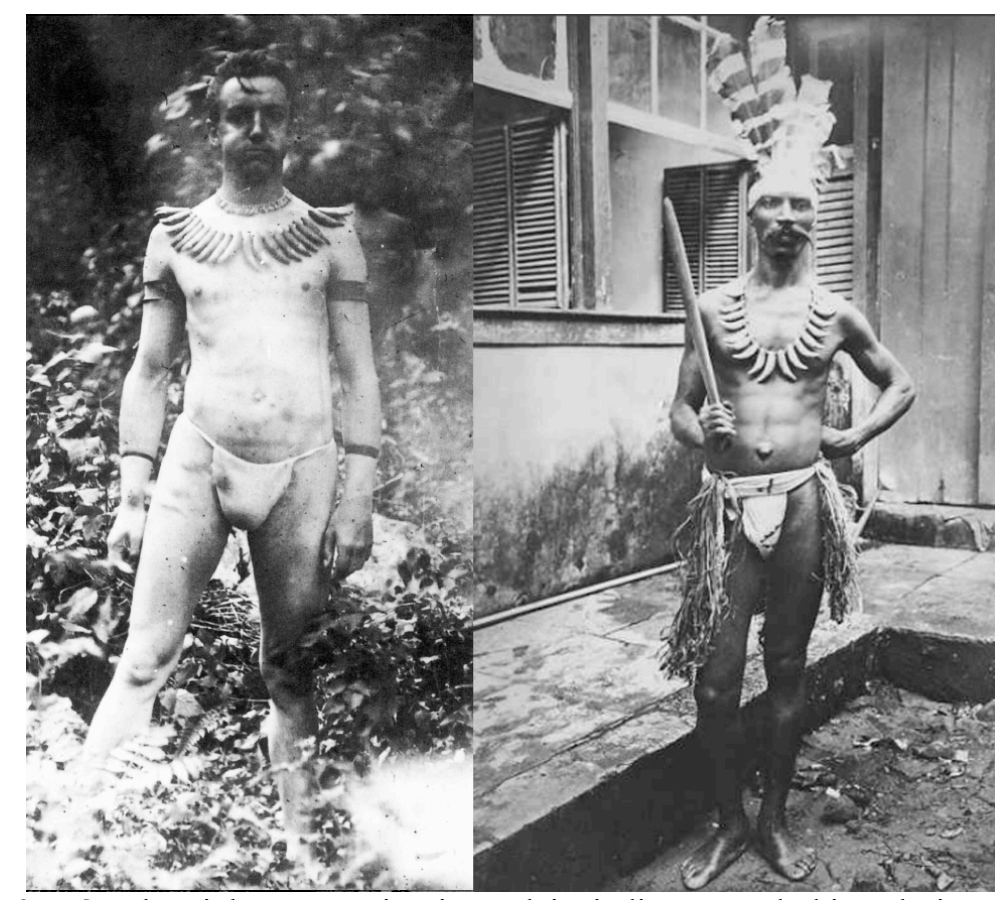

3.5 On the right Brown is pictured in indigenous clothing during the consular expedition to the Putumayo of 1912 in which he acted as interpreter (see Capparro M. and A. Chirif 2013). The photograph echoes an earlier one, probably taken by Brown of Whiffen in 1909 (left) similarly dressed (see Cadbury 2004). Elements of mimesis, role-play and 'signifying' are foregrounded.

The two seem to have become good friends-Whiffen as master and Brown as paid servant. There are a number of photographs taken by Whiffen of a smiling Brown, smartly dressed, suggestive of playful collusion between the two. Other pictures, probably taken by Brown, show Whiffen adopting an ironic posture in indigenous garb or smoking his pipe in the company of suavely dressed Peruvian 
Freedom in Practice: Governance, Autonomy and Liberty in the Everyday

Moises Lino e Silva and Huon Wardle [PREPUBLICATION VERSION] (2016)

overseers. 'What are you doing with ese gringo cojudo ${ }^{16}$ (this dumb whiteman)?' they asked Brown. Brown had learnt the local languages (including the seemingly difficult Bora) in the course of his work for Arana's company whereas even Whiffen's Spanish was mediocre: Whiffen was dependent on him for an interpretation of the Amerindian villages they entered.

Since Whiffen and Brown never left the rubber trail, Whiffen was never outside the sphere of operations of one or other of the rubber-gathering stations, nor, despite the title of his monograph, did he ever gather any significant evidence of cannibalism. He never went to the Jaipura falls where Robuchon had last been seen-instead passing off a description given him by Brown as his own first-hand account (Echeverri 2013:4344). The presentation of himself in his monograph-intrepid flagbearing Briton entering uncharted territory in search of cannibals - was a self-aware fiction (Taussig 1987, Cadbury 2004). Brown, in his temporary role as a British colonial subject, was nonetheless engaged in a dangerous subterfuge with Whiffen that could have ended with both of them being killed by Arana's operatives.

$* * * *$

\section{Ellipsis 1}

According to the account he gave Gomez Valderrama much later, but again contradicting his witness testimony, Brown left South America with Whiffen for London in 1909.17 He was living happily in the island of Montserrat with his then girlfriend when the request for a witness statement arrived in 1910. However, secondment as an interpreter for Casement's inquiry, then as the interpreter for the consular investigation of 1912 drew him back (this time he would tell consular officials that he had been born in Montserrat). Ultimately John Brown spent the rest of his life in the Amazon. In 1934 he participated on the side of the Colombians in a border war with Peru and this eventuated in Brown becoming a resident of Colombia. Ramiro Rojas, his grandson, tells how, in old age, Brown enjoyed listening to U.S. foreign broadcasts of politics shows and evangelical preaching. ${ }^{18}$ In 1971, in search of Amazonian hallucinogens, ethnobotanist and psychonaut Terence McKenna stumbled across John Brown at his house on the banks of the Putumayo river:

We soon reached a ramshackle and undistinguished house with a small yard hidden behind a tall board fence... A large pig lay in the lowest, wettest part of the yard; three steps up was a veranda. Upon the veranda, smiling and motioning me forward, sat a very 
Freedom in Practice: Governance, Autonomy and Liberty in the Everyday

Moises Lino e Silva and Huon Wardle [PREPUBLICATION VERSION] (2016)

thin, very old, much wrinkled black man: John Brown. It is not often that one meets a living legend and, had I known more about the person I confronted, I would have been more respectful and more amazed.

"Yes," he said, "I am an American." And, "Yes, hell yes, I am old, ninety-three years. Me hee-story, baby, is so long." He laughed dryly, like the rustle of roof thatch when tarantulas stir (McKenna 1993:10)

\section{Ellipsis 2}

Perhaps the scars were as old as John Brown himself-ninety-eight years. His grandson, Ramiro Rojas tells us that, in 1977, when his grandfather, John Brown, died and the family gathered at the little house in the Colombian borderlands to prepare his body for burial, they found that onto the sole of each of his feet was incised a cross. They wondered if the marks had been passed on from the days of slavery by Brown's grandparents; maybe the index of a protective ritual, concealed but irrevocable (Rojas Brown 2010). Reading this, and knowing some of his history, it struck me how ambivalent a sign the cross has been in African American history. Not only have ambiguous powers been drawn from its intersecting lines - by journeying to a crossroads for example; but from fieldwork, I remembered too the creole vernacular expression 'crosses are go follow you' where the cross signals death and holds, in that sense, bad, not good, luck. Leaving the spirit of the deadone dancing and confused at a fork in the road is often the last act of a West Indian wake. Thought of in that way, the cross is a primary index of the activity of 'signifying' or 'telling lies' where, as Zora Neale Hurston describes it, a 'lie' is not defined by the 'intention to deceive' but is rather as a licence to ambiguate (1990). 'Signifying', as Henry Louis Gates points out, does not involve arriving at a final meaning, but rather evading one; as such it becomes a necessary tool for journeying, for remaking the self in space and for localising certain kinds of contingent freedom (1988). Signifying 'evokes Esu, the little man whose earthly dwelling is the crossroads... a discursive crossroads at which two languages meet, be these languages Yoruba and English, or Spanish and French, or even (perhaps especially) the black vernacular and Standard English' (Gates 1988:65). 


\section{The Meaning of Liberalism}

Wherever we lay the emphasis in terms of cause and effect, it is clear that the discourse on personal freedom and tolerance that we now call Liberalism crystallised at the end of the Eighteenth Century in the same decades when the first conceptions of Capitalism and Individualism also appeared. ${ }^{19}$ Adam Smith sketched how these three notions cohere in his Wealth of Nations (1776). The more that traditional forms of work and exchange are transformed by the use of money, he argued, the more the individual becomes freed to dispose of their capacities on their own behalf (as a worker, owner or entrepreneur). Traditional circles of political sympathy and antipathy break down with the constantly revised division of labour, and new objectives for free action open up that replace customary restrictions: group loyalties and hierarchies are less and less constraining on the individual's freedom to transact with others. In Tawney's words, the new contract implied 'freedom to move, freedom to buy and sell and invest-the emancipation, in short of property and enterprise from the restraints which fettered them'. Supposedly grounding this general principle was another of Liberalism's fundamentally ambiguous ideas - 'equality of opportunity' (1964:109). Amongst Anglophone West Indian workers that concept was expressed in the distinctive phrase 'I'm an Englishman too'.

In response to Smith's liberal utopianism, Marx would insist that this notional liberty that capitalism makes available to the wage worker is merely freedom to be enslaved or enserfed in a new way: a fact, he argued, that is 'completely masked by the intervention of a contract and... pay at the end of the week' ([1898]1965:51).' Contract labour was if anything more perfectly exploitative than slavery or serfdom, Marx argued. The importance West Indian workers attached to working to a contract is notably at odds with Marx's view. In 1906 Barbadian workers in the Putumayo sent a letter to the Barbados Advocate complaining that the Peruvian Amazon Company had -

not delt with us according to the Contract they took us from Barbados as labours. After we reach there they refuse to give us any wages according to the Contract saying they pay the Government of Barbados a Sum of $£ 150$ for each of us and now we are Suffering day by day as Slaves we thought that we was going there as labours but we found out afterwards there is Slaves where we are. (in Richardson 1985:110)

The emphasis these workers place on the fact of there are 'Slaves where we are' in contrast to their own status as contract workers is significant: the treatment of the indigenous workers in the Putumayo was slavery 
Freedom in Practice: Governance, Autonomy and Liberty in the Everyday

Moises Lino e Silva and Huon Wardle [PREPUBLICATION VERSION] (2016)

in their view (see Peter Gow's essay in this volume, though, for the view of Amerindians themselves which challenges taken for granted meanings of 'slavery'). In other words, six decades after emancipation, West Indian emigrants took very seriously British colonialism's (utilitarian) rhetoric concerning 'the labourer's freedom to dispose of his labour wherever seems best to himself' ${ }^{20}$ If for Marx the distinction between slave and contract work was merely terminological, for the Barbadian workers, who knew the difference, the contrast was real and telling.

However, as Georg Simmel comments (he gives over a long chapter of his Philosophy of Money to a discussion of money and individual freedom'); The exercise of freedom in societies oriented toward liberal individualism and the 'money wage' shows itself not primarily as a unified set of cultural expectations but rather as a state of uncertainty that parallels the breakdown in recognisably shared expectations:

The manner in which freedom presents itself is as irregularity, unpredictability and asymmetry. This is why liberal constitutions like the British are characterized by internal anomalies, lack of organization and systematic structure, whereas despotic compulsion culminates in symmetric structures, uniformity of elements and avoidance of anything that is improvised" (Simmel [1911] 2009:338).

Undoubtedly, the cultural shapes that Liberalism took were unprecedented and distinctive, not least because, at the institutional level, upholders of the liberal constitution enjoyed pointing to the kinds of meritocratic disorder that liberal policy produced. What the term meant also changed; from Bentham's stark radicalism-'every individual... tells for one, no individual for more than one', to the social liberalism of T.H. Green ${ }^{21}$ for whom redistribution of social goods was necessary for the self-development of the mass of citizens; in other words a recognition, as Polanyi sardonically suggests, of a need for state planning in the operation of laissez faire (1957:135-162). Simmel is, then, describing the British imperial liberal compromise at its highpoint and as it appeared to him at the turn of the Twentieth Century. This is the period in which the idea of 'laws of humanity' first appears as a realisable possibility. ${ }^{22} \mathrm{He}$ is, hence, annotating a world very different to the checkerboard of bounded nation states that emerged after 1918. Maynard Keynes, ${ }^{23}$ Bronislaw Malinowski, and others like Stefan weig, would look back at this high-point of imperial liberalism with nostalgia: 
Freedom in Practice: Governance, Autonomy and Liberty in the Everyday

Moises Lino e Silva and Huon Wardle [PREPUBLICATION VERSION] (2016)

Before 1914 the earth belonged to the entire human race. Everyone could go wherever he wanted and stay there as long as he liked. No permits or visas were necessary, and I am always enchanted by the amazement of young people when I tell them that before 1914 I travelled to India and America without a passport. You boarded your means of transport and got off it again, without asking or being asked any questions; you didn't have to fill in a single one of the hundreds of forms required today (Zweig [1942]2009:436).

John Brown's travels as a ship's stoker were not the frictionless passage that Zweig pictures, but the very deep ambiguity of the liberal imperial project did allow him fleeting conjunctions in which his freedom could be expressed-even in the shape of actual political liberty. The culture of British imperial liberalism was, then, a far more ambiguous phenomenon than it is often understood to be when taken as the ideological counterfoil of capitalist exploitation. Garveyism, for instance, the political expression of black trans-Caribbean workers par excellence was, in its public symbolism, cut from liberal imperial cloth. Refigured, liberal imperialism offered the syncretic outer surface for black migrant utopia. After 1918, Social scientists would reframe the Caribbean turning a history of movement into a study of static island societies, emergent nation-states in the Wilsonian or American Century that followed. Garvey would come to seem inexplicably eccentric, in image at least an apologist for a certain type of out of date imperial grandiosity; but not to ordinary West Indians for whom possibilities for freedom through movement continued to guide their ideas about kinship, religion and landscape $(2000,2011,2013)$.

\section{Concluding remarks}

Malinowski, unusual amongst anthropologists in the attention he paid to the topic, argued that any definition of freedom that prioritises subjective imagining will jeopardise coherence: comprehension of freedom as it objectively exists is lost to 'semantic chaos' when put on a par with the subjective wishful thinking of particular individuals. $\mathrm{He}$ had in mind the particular contemporary danger posed by the Nazi coup d'etat: Nazi fellow travellers might well imagine themselves to be individually free even while Nazi activists destroyed the institutional fabric supporting civil liberty. We should restrict our comments on freedom to analysis of the role of free action in creating objective social effects, he argued. As social scientists we should entirely avoid talking about the subjective qualities of freedom because it is utterly impossible to coordinate these with an objective assessment. 
Like many of his generation, Keynes, Zweig, Malinowski24 looked back wistfully to the values of late Nineteenth and pre-World War I imperial liberalism as a stark contrast with the ugly and murderous politics of post-war totalitarianism. None of them, of course, had experienced liberal imperialism through the eyes of a manual worker on one of its projects. Whether we agree with Malinowski's way of assessing the problem or not, the work of reconstructing some particular individual's intuitions and concepts of freedom is clearly doubly difficult. First, taking on this task assumes that we can gain privileged access to their private sphere of imagining; that we can adopt their perspective on the world as an imaginative project for ourselves. Second, the relationship between public exterior effects, reflected in phrases like 'civil liberty', and the individual's intuiting, imagining and planning is inevitably highly ambiguous. Malinowski was surely right that a purely subjectivist account of freedom arrives at a dangerously solipsistic view of liberty: but is it not equally true that a purely objective account that ignores the moments of coordination, mis-coordination and approximation between imagined and publically declared freedoms runs the risk of becoming, in human terms, meaningless?

References.

Abbot, W. 1913. Panama and the Canal in Picture and Prose. New York": Syndicate Publishing Company.

Bagehot, W. 1873. Physics and Politics. London: King \& Co.

Benson, S. 2006. 'Injurious Names: Naming, Disavowal and Recuperation in Contexts of Slavery and Emancipation' in Benson, S. (ed.) The Anthropology of Names and Naming. Cambridge: Cambridge University Press.

Cadbury, T. 2004. 'Imagining the Amazon: The Whiffen Collection at Cambridge'. Journal of Museum Ethnography, 16(March):85-100.

Casement, R.1997. The Amazon Journal of Roger Casement. Dublin: Anaconda.

Chapparro, M. and Chirif A. 2013. 'Introducción' in Álbum de Fotografías: Viaje del Comisión al Rio Putumayo y sus Afluentes, Agosto a Octubre de 2012.' Iquitos: Programa de cooperación Hispano Peruano.

Chirif, A. 2004. 'Introducción' in El Proceso Del Putumayo y Sus Secretos Inauditos. Iquitos: CETA.

Chomsky, A.1996. West Indian Workers and the United Fruit Company in Costa Rica, 1870-1940. Baton Rouge: Louisiana State University Press Clark, K.1997. The Redemptive Work: Railway and Nation in Ecuador 1895-1930. Wilmington: Scholarly Resources. 
Freedom in Practice: Governance, Autonomy and Liberty in the Everyday Moises Lino e Silva and Huon Wardle [PREPUBLICATION VERSION] (2016)

Cohen, A. 1994. Self-Consciousness: An Alternative Anthropology of Identity. London: Routledge.

Crichlow, M. 2009. Globalization and the Post-Creole Imagination.

Durham: Duke University Press.

Echeverri, J. 2013. 'La Suerte de Robuchon' in Robuchon, E. (au.) En el Putumayo y Sus Afluentes. Lima: Biblioteca del Gran Cauca.

Enock, R. 1912. 'Introduction' in Hardenberg, W. The Putumayo: The Devil's Paradise. London: Fisher Unwin.

Garvey, M. 1967. Philosophy and Opinions of Marcus Garvey (edited by Amy Jacques Garvey). New York: Atheneum.

Gates, L. 1988. The Signifying Monkey: A Theory of African-American Literary Criticism. New York: Oxford University Press.

Gomez Valderrama, P. 1984. Los Infiernos del Jerarca Brown y Otros

Textos. Bogota: Fundación Simon y Lola Gubarek.

Gomez, C. 2013. 'John Brown Va Hacia Donde Nace El Sol' El

Colomiano, November.

Greene, J. 2009. The Canal Builders: Making America's Empire at the Panama Canal. London: Penguin Books.

Hall, R. 1991. The Marcus Garvey and Universal Negro Improvement Association Papers Volume VII, November 1927 - August 1940. Hall, R. 2008. 'King Menelik's Nephew: Prince Thomas Mackarooroo, aka Prince Ludwig Menelek of Abyssinia'. Small Axe, June: 15-44. Harris, W. 1970. 'History, Fable and Myth in the Caribbean and Guianas'. Caribbean Quarterly, 54(1/2): 5-38.

Haskin, F. 1913. The Panama Canal. New York: Doubleday, Page \& Co. Hurston, Z.N. [1935]1990. Mules and Men. New York: Harper and Row. Johnson, H. 2002. 'Barbadian Migrants in the Putumayo District of the Amazon 1904-1911.' In Chamberlain, M. (ed.) Caribbean Migration:

Globalised Identities. London: Routledge.

Kant, I. 2006. Anthropology from a Pragmatic Point of View.

Cambridge: Cambridge University Press.

Keynes, J. 1920. The Economic Consequences of the Peace. New York: Harcourt, Brace and Howe.

Luxembourg, R. [1913]1951. The Accumulation of Capital. New Haven: Yale University Press.

Malinowski, B. 1944. Freedom and Civilization. New York: Roy Publishers.

McKenna, T. 1993. True Hallucinations: Being an Account of the Author's Extraordinary Adventures in the Devil's Paradise. London:

Ebury.

Olwig, K. 2010. 'Cosmopolitan Creolisation, Cosmopolitan Traditions:

Caribbean Perspectives' in Rapport N. and H. Wardle (eds.) A Cosmopolitan Anthropology, Special Issue of Social Anthropology, 18:4. 
Freedom in Practice: Governance, Autonomy and Liberty in the Everyday Moises Lino e Silva and Huon Wardle [PREPUBLICATION VERSION] (2016)

Páramo, C. 2004. . 'El Camino Hacia La Vorágine' Essay toward the Master's degree in anthropology, National University of Colombia. Reisman, K. 1971 “Cultural And Linguistic Ambiguity: Some Observations On The Role Of English-Based Creole In An Antiguan Village" in Dell Hymes (ed.) Pidginization and Creolization of Languages . Cambridge: Cambridge University Press.

Rojas Brown, R. 2010. 'Una Nueva Mirada a las Caucherias: Economia del Terror. John Brown un Personaje de Leyenda y Testigo de Excepción'. MA Thesis; National University of Colombia. Rush, A. 2011. Bonds of Empire: West Indians and Britishness from Victoria to Decolonization. Oxford: Oxford University Press. Senior, O. 2014. Dying to Better Themselves: West Indians and the Building of the Panama Canal. Mona: University of the West Indies Press.

Sheller, M. 2012. Citizenship from Below: Erotic Agency and Caribbean Freedom. Durham: Duke University Press.

Simmel, G. [1911] 2009. The Philosophy of Money. London: Routledge. Taussig, M.1987. Shamanism, Colonialism and the Wild Man: A Study in Terror and Healing. Chicago: Chicago University Press.

Tawney, R. 1964. Equality. London: Unwin Books.

Thomas-Hope, E. 1995. 'Island Systems and the Paradox of Freedom' in K.F. Olwig (ed) Small Islands, Large Questions. London: Frank Cass. Twain, M. 1883. Life on the Mississippi. Boston: James Osgood \& Co. Veblen, T. 1904. The Theory of Business Enterprise. New York: Charles Scribner \& Sons.

Wardle, H. 2000. An Ethnography of Cosmopolitanism in Kingston, Jamaica. New York: Edwin Mellen.

2011. 'The Double Life of M.G. Smith: Rethinking Caribbean Citizenship Beyond, Between and Within the National Frame' in Meeks, B. (ed.) M.G. Smith. Kingston: Ian Randle.

Wardle, H. 2013. 'Negro with a Hat': a Review Essay. OAC press. (http://openanthcoop.net/press/2013/01/19/negro-with-a-hat/) Wilson, P.J.1974. Oscar: A Study in the Nature of Sanity? New York: Random House. 
Freedom in Practice: Governance, Autonomy and Liberty in the Everyday

Moises Lino e Silva and Huon Wardle [PREPUBLICATION VERSION] (2016)

Notes.

1 'Peruvian Amazon Co.' Correspondence between the Colonial Office and the Foreign Office January to March 1910. Kew Gardens: National Archives.

${ }^{2}$ Casement may have coined this phrase for the first time in his Amazon Journal, 1997:178.

3 'Peruvian Amazon Co.' Correspondence between the Colonial Office and the Foreign Office January to March 1910. Kew Gardens: National Archives.

${ }^{4}$ See the theoretical introduction to this volume for more on the Enlightenment view the centrality of human freedom versus the social scientific critique of naïve freedom ideas (Kant [1798]2006:3).

${ }^{5}$ Cf. Cohen, A. (1994) for an extended critique of this approach in anthropology.

6 'remodeling' and 'code-switching' are terms used by linguists and anthropologists of the Caribbean to examine the situational adaptation of linguistic and cultural performance in Creolised cultural or linguistic settings where there exists a wide continuum of possibilities for communication.

Hence, utterance can be adapted to be sound, or to have a syntactic structure, more or less like the dominant form (e.g. Reisman 1970).

7 'Introduction' in The Putumayo: The Devil's Paradise (C. Reginald Enock 1912:48).

8 The model of 'primitive accumulation' focused on forced labour, is a central theme of Rosa Luxembourg's 1913 treatise The Accumulation of Capital. New Haven: Yale University Press.

9 Páramo, C. 'El Camino Hacia La Vorágine’ Essay toward the Master’s degree in anthropology, National University of Colombia, 2004:47. Mario Gomez, C. 'John Brown Va Hacia Donde Nace El Sol' El Colomiano, November, 2013.

10 The evidence for this being a specific reference to John Brown is speculative, but not excessively so. We know that Brown was one of only a few of the black workers who spoke Bora and he remained in the region after the other black migrants had left which may explain why he stands out in this account.

${ }^{11}$ Between 1861 and 1921 Barbados experienced net emigration in excess of 100,000 persons. Roberts, G. W. 'Emigration from the Island of Barbados.' Social and Economic Studies 4, no. 3 (1955): 245-288. The years of the Panama Canal construction coincided with a sustained fall in the population on the island of Barbados from 182,000 in 1891 to 156,000 in 1921 (Richardson 1985:170).

12 See House of Commons Parliamentary Papers:1913 (148) Report and special report from the Select Committee on Putumayo, together with the proceedings of the committee, minutes of evidence and appendices.

${ }^{13}$ Chomsky, A. 1996. 
${ }_{14}$ Casement, R. The Amazon Journal of Roger Casement. Dublin: Anaconda Editions, 1997:104.

${ }^{15}$ Interview by Irene Robertson with Lee Guidon in: WPA Slave Narrative Project, Arkansas Narratives, 2(3):120. Library of Congress 1936-1938.

16 'cojudo' - an idiomatic Peruvian insult. In Rojas Brown 2010:37.

${ }^{17}$ Gomez Valderrama 1984:58-59. The truth is further clouded by the fact that Gomez insisted on writing that Brown had travelled with Walter Hardenberg, even though Brown spelt Whiffen's name out for him (1984:56). The friendship between Brown and Whiffen is the subject of forthcoming research.

${ }_{18}$ Rojas Brown 2010.

19 The Oxford English Dictionary dates 'Liberal' in its modern sense of 'free from bias, tolerant' to the $1770 \mathrm{~s}$ - contemporaneous with the first use in print of 'Capitalist'. In the Wealth of Nations Smith does not talk of 'Individualism', which emerged a few decades later in common parlance, but, as a concept, the ideal of a self-bettering rational individual is omnipresent.

${ }^{20}$ Papers Relating to Her Majesty's Colonial Possessions. Reports for 1885 and 1886 , page 43 .

${ }^{21}$ E.g. See Ritchie, D. 1896:145-151. The Principles of State Interference: Four Essays on the Political Philosophy of Mr Herbert Spencer, J.S. Mill and T.H. Green. New York: Books for Libraries Press.

${ }^{22}$ Cf. Hague IV (1907): Convention Respecting the Laws and Customs of War on Land.

${ }^{23}$ See Keynes' opening remarks in The Economic Consequences of the Peace (1920) where Keynes' compares the liberal compromise before World War I with the dangerous situation brought about by the Versailles Treaty.

${ }^{24}$ Zweig, Keynes and Malinowski were born within five years of each other. 